\title{
Indexing political identity in the Catalonian procés: \\ A sociophonetic approach
}

\author{
JOSÉ LUIS BLAS-ARROYO \\ University Jaume I, Spain
}

\begin{abstract}
This article demonstrates the potential for phonological variables to be a resource for the expression of ideology and identity in historical circumstances such as those experienced recently in the Catalonian procés. Based on a corpus consisting of communicative events from sixteen leading Catalan politicians, four Spanish linguistic variants are analyzed. Apart from a handful of structural predictors, the mixed-effects logistic regression analysis shows the robustness of (only) two extralinguistic factor groups: the social origin and the identification of the politicians as Catalan nationalist (mainly pro-independence) or not nationalist. As regards the latter, the most significant of all predictors, the analysis shows how nationalist politicians always favor the sounds mainly associated with vernacular pronunciation in eastern Catalan speech communities ([-1] and [-t]), but at the same time also favor other sounds associated with more canonical and pan-Hispanic prestige variants ([-ð] and [-ð-]). These apparently contradictory results can be explained if the social meaning of all variants is considered around the same indexical field, that of authenticity. In this sense, nationalists seem to 'appropriate' the Spanish language by tingeing its expressive habits with uses closer to their language. (Phonological variation, nationalism, ideology, languages in contact, Spanish, Catalan)*
\end{abstract}

\section{INTRODUCTION}

In recent years, third-wave variationist analysis has witnessed an increasing interest in studying the agentive nature of variation. Within this line of research, variation is not a mere reflection of macro-sociological constructs, such as sex, social class, age, social networks and so on, but also the place for potential acts of indexicality, by means of which speakers (re)create social meanings again and again (Kiesling 2009; Jaffe 2009; 
Snell 2010; Eckert 2012, 2016; Drummond \& Schleef 2016; among others), even if this agentivity is not always conscious (Bucholtz \& Hall 2010).

One of the fields of study where this agentivity takes on special significance is political discourse. For instance, in the last few years it has been noted that the phonetic level has become fertile ground for researching the indexical meanings conveyed by the pronunciation of certain variables. Researchers' attention has sometimes focused on the way in which a public figure can manipulate the same resource depending on the audience they are addressing, as exemplified in a study by Kirkham \& Moore (2016) regarding the pronunciation of $/ \mathrm{t} /$ in especially salient words in British political discourse. For example, in words like Britain and government, the former British Labour leader Ed Miliband pronounced significantly more glottal forms of /t/ before a trade union audience than before his party colleagues at the annual Labour Conference. For the most part, these stylistic differences have more commonly been addressed by comparing the behaviour of representatives of different political formations, separated by relevant ideological and strategic differences. For example, in a study on the extent to which the foreign (a) vowel was integrated within foreign words such as Iraq among US politicians, Hall-Lew, Coppock, \& Starr (2010) found that the uses that most faithfully follow the original pronunciation [a:] occur among the Democrat representatives, while among Republicans adaptation to the phonetics of English [æ] was more frequent, even with some examples of idiolectal variation inside both groups. Hall-Lew, Friskney, \& Scobbie (2017) also showed how convergence towards the standard norm of British English among Scottish politicians is closely correlated with their ideological identity, so that Labour politicians converge significantly more than members of the Scottish Nationalist party with respect to some phonetic variants. Likewise, in post-Soviet Ukraine, the choice of the prepositions $n a$ and $v$ in the sequence 'in Ukraine' also appears to be marked by the political affiliation of the speakers, the first variant being preferred by the Ukraine nationalists and the second by pro-Russian followers (Krivoruchko 2008).

The different social meanings of these stylistic variations have also been confirmed in reception. Podesva, Reynolds, Callier, \& Baptiste (2015) demonstrated how the evaluation of released / $t$ / among US political audiences is constrained by both linguistic and social factors. With regard to the latter, interpretations depended on the linguistic identity that members of the audience conferred upon politicians, and in particular their degree of knowledge about the frequency with which these politicians 
use the variant in question. Likewise, Schrimpf (2013) discovered that people who voted for the Republican party in the state of Tennessee were more sensitive to the effects of the Southern Vowel Shift than those who voted for the Democrats. Lastly, in her study of the correlations between local dialects and prevalent political views, Knoblock (2014:4) also concluded that: 'the respondents tended to assign political affiliation of speakers unfamiliar to them in line with the speakers' dialectal features and assumed that strangers whose dialect is similar to their own shared political views also similar to their own'.

As in other spheres of sociolinguistic research, far less attention has been paid to this line of research in the case of peninsular Spanish. With the present study, I try to fill this gap by focusing attention on the speech of several politicians in the Catalonian procés, the movement in favour of the independence of the Spanish region of Catalonia that has made headlines around the world. As the data in this study will show, the analysis of the political and ideological affiliation of politicians is particularly intriguing in this context as it is the main predictor in explaining some areas of phonological variation.

In the next section, I present the main objectives and hypotheses of this study within a particular sociohistorical context - that of Spanish in contact with Catalan. The main hallmarks of the Catalan independence procés are then summarised. In the following sections, I describe the most relevant aspects of the corpus, the linguistic variables examined, the coding process, and the variationist methodology used for the analysis of the data. The most significant results derived from this analysis are presented and discussed in the main two paragraphs, while the last section summarised the most salient theoretical implications of the study.

\section{BACKGROUND AND OBJECTIVES}

Spanish and Catalan have coexisted in Catalonia and other north-eastern regions of the ancient Corona de Aragón (Valencia, Balearic Islands) since at least the late fifteenth century (Sinner 2004:9-18). However, the evolution and intensity of this contact have varied significantly at different points in time. Until the end of the eighteenth century, Spanish was largely unknown to most of Catalan society, especially in the more rural areas. Around that time, Spanish only affected the dominant classes, particularly following the enactment of the Nueva Planta 'New political order' decrees (1707-1716) 
after the War of the Spanish Succession, which imposed the use of Spanish as the official language at the expense of Catalan. From the second half of the nineteenth century onwards, the restratification of Catalan society (which benefited the bourgeoisie) along with educational reforms and compulsory military service meant that Spanish was favoured by social groups and in domains that had been traditionally linked to Catalan. Yet, it was not until the twentieth century (and above all with Franco's dictatorship) that the process of substitution was to reach its highest levels. This situation was caused both by ideological factors (the repression of autochthonous languages and cultures) and by the arrival of vast numbers of Spanish-speaking immigrants from other regions of Spain throughout the long period of intense industrialisation and urbanisation that took place from the 1960s onwards (Sinner 2004; Blas Arroyo 2004, 2011). However, following the restoration of democracy in Spain in the late 1970s, the sociolinguistic landscape in these territories has undergone significant changes, largely due to the process of normalisation of vernacular languages such as Catalan. As a result, since the early 1980s, both Spanish and Catalan have been declared official languages in the Comunidad Autónoma Catalana, although the latter's recognised status as llengua propia 'own language' had served to justify its privileged use in the public sphere (Parliament, government, educational system, etc.).

As far as contact linguistics is concerned, it is only in recent decades that Spanish linguistics has become interested in the study of varieties of Spanish in contact with Catalan, moving away from the traditional view of them as no more than adstratal varieties or even as mere errors of performance made by the less educated sectors of society (Sinner 2004; Blas Arroyo 2004, 2011). Indeed, these negative attitudes towards the Spanish spoken - and even written - in this part of Spain have been largely reactivated in folk linguistics among several sectors of society who have drawn attentionto the precarious status of Spanish among more and more segments of the Catalan population. According to the strongest critics, there would be several reasons explaining this state of affairs, but they find a common nexus in the language policy followed by nationalist governments in this region, which has imposed compulsory language immersion in Catalan throughout the whole educational system for the last three decades (for more details on these programmes, see Hawkey 2014). This would explain - always according to these critics - why those who have Catalan as their native and dominant language end up acquiring an imperfect command of Spanish and, at the 
same time, why those who have Spanish as their mother tongue are also unable to have sufficient academic proficiency in their own language.

Criticism has become more intense in recent years in describing the language of Catalan politicians based on excerpts like those below produced at the height of the referendum for independence in 2017. These show a strong influence of contact with Catalan, and would illustrate the alleged precariousness of the Spanish spoken in Catalonia, even among a group of speakers for whom an appropriate use of both the Catalan and the Spanish languages is presumed.

(1) no sabían exactamente de cuál era la magnitud perquè visto lo que había sucedido diumenge... ay perdón ( $e l$ domingo evidentemente se sentían abs(ol)utamente decepcionados (Monserrat Candini, 3-10-2017) 'they didn't know exactly the full extent of it because in view of what happened Sunday, oops, sorry, (on) Sunday, they obviously felt absolutely disappointed'

(2) y creemos que también ha estado esto decisivo para poder convocar un acto de de rebuig (Joaquim Forn, 31-08-2017)

'and we also believe that this has been decisive to be able to... organise an act of... of rejection'

(3) si el presidente Rajoy ha decidido convocar con el soporte... con el apoyo de Ciutadans y del PSOE estas elecciones es para aceptar su resultado y amb bas... en base a este resultado (Marta Rovira, 29-11-2017)

'if president Rajoy has decided to call these elections with the support... with the backing of Ciutadans and the PSOE, it is to accept the results and with the bas... on the basis of this result'

In these transcripts we find a range of language contact outcomes, such as direct loans (perquè, diumenge, rebuig, amb), semantic (soporte vs. ayuda) and syntactic calques (ha estado vs. ha sido; domingo vs. el domingo), code-switching (diumenge, ay perdón domingo; de rebuig... de repulsa), phonetic interferences (voicing of /s/, amalgam of closed vowels in an unstressed position, abs(ol)utamente).

How to explain so many vernacular traits in the Spanish spoken by these politicians? Are they simply the consequence of mass exposure to Catalan? Or to a language policy that neglects the role of Spanish as a language of education? 
In my opinion, simply answering in the affirmative to these latter questions is problematic in this particular case. First of all, the proliferation of vernacular traits, of which fragments (1) to (3) are a small illustrative sample, is less expected among politicians who, for the most part, belong to the sociocultural elite, with a higher level of education and a comfortable financial position. Moreover, in many of these casesand examples (1) to (3) are representative - the speakers, due to their age, have not been subject to compulsory language immersion in Catalan. If anything, it is quite the contrary: during the years of Franco's dictatorship they were forced to study entirely in Spanish. It is therefore unlikely that the so-called 'deficit' in Spanish can be attributed simply to mass contact with Catalan.

Conversely, could it be the case that those who (re)produce these systematic language contact traits in their speech do so in an attempt to 'appropriate' a language, like Spanish, which they do not consider either their language nor the national language of Catalonia, but still have to use due to their public position in an officially bilingual society? In short, in a historical moment such as the present, in which the future relationship between Catalonia and Spain is under debate, could these vernacular traits be interpreted as potential acts of identity (Le Page \& Tabouret-Keller 1985) or indexical acts (Eckert 2008) to which certain social meanings are associated, rather than (or at least not only) as a mere reflection of the social and dialectal origin of its speakers?

In this study, I set out from this hypothesis, which I test by analysing various phonetic variables. Previous research has noted the presence of several pronunciations in Spanish that are directly related to contact with Catalan, and which differ quantitatively and qualitatively from others that we find in other domains of peninsular Spanish. The initial premise is, therefore, that the repetition of these same sociolinguistic patterns would be the correlate of similar social meanings that tend to exalt local forms. The main particularity offered by the community under study here, however, is that the sociolinguistic patterning by individuals and social groups may entail two types of variants. In some cases, it favours the realisation of vernacular forms, commonly indexed as typical regional stereotypes (Labov 1972; Silverstein 2003; Eckert 2016). In other cases, the uses coincide with the most prestigious variants in Spanish. Yet, this seeming contradiction is only illusory. Ultimately, it is the product of the same process - a process by which the forms that lie closer to Catalan phonology are promoted, regardless of their social value in Spanish. 


\section{THE CATALAN PROCÉS}

Over the last few years the Catalan pro-independence procés has become an issue with immense media repercussions. There are a number of complex reasons underlying this. In practice, the more nationalist Catalan sectors have never hidden their longing for sovereignty, as shown by a number of events in the last century, such as the declaration of the independent Catalan state in October 1934 by the Catalan Regional Government (Casanova 2007). Following the restoration of democracy in Spain, after the death of Franco (1975) and the creation of the Estado de las Autonomías (Regional State) in the early 1980s, that longing was largely moderated. Nevertheless, in the early days of the twenty-first century, a series of events were to rekindle the pro-independence movement, which would gradually smoulder its way through increasingly wider social sectors that wanted to undertake the decisive process of secession. This was the case with the 2008 financial crisis, which affected the whole country, and was inextricably linked to the massive protests against the decision of the Constitutional Court (2010) regarding the Statute of Catalonia. With this judgement, the High Court amended a number of articles of the Estatut passed in a referendum in 2006, including one in which Catalonia was considered a nation. This was followed by the breakdown of negotiations aimed at granting this autonomous community a more favourable tax status.

All of this resulted in, as of 2012, certain sectors of Catalan society embarking upon a process in favour of independence from the Spanish state (for more details about this process, see Dowling 2014). This procés, which received widespread media coverage, included a number of milestones, such as multitudinous demonstrations on the annual Diada day (every 11th September) with previously unseen numbers of participants; two referendums, the first one in November 2014, which was not considered binding even by the nationalist authorities, and the second on October 2017. Following a period of considerable outcry when the laws of 'disconnection' and referendum passed by the nationalist forces in the Catalan parliament were unanimously rejected by the non-nationalist parties, this second referendum was finally held on 1 October 2017. Throughout that day, there were a number of clashes between citizens who wanted to vote and the forces of law and order sent in by the Spanish government in order to prevent the vote. Images of these events were shown all over the world. 
The data analysed in this study extends over a whole decade, from 2007, shortly after the approval of the current Statute of Catalonia, to the election campaign in December 2017.

\section{THE CORPUS}

Table 1 summarises the backgrounds of the sixteen Catalan politicians whose political speech acts comprised the Spanish spoken corpus analysed in this article. All played a prominent role in the sovereignty debate in the pivotal year of 2017.

TABLE 1. Some personal and social details of the members of the sample.

\begin{tabular}{|c|c|c|c|c|c|c|}
\hline NAME & $\begin{array}{c}\text { POLITICAL } \\
\text { PARTY }\end{array}$ & GENDER & $\begin{array}{l}\text { BIRTH } \\
\text { YEAR }\end{array}$ & $\begin{array}{l}\text { SOCIAL } \\
\text { STATUS }\end{array}$ & IDEOLOGY & $\begin{array}{c}\text { CATALAN } \\
\text { NATIONALIST }\end{array}$ \\
\hline Albiol, Xavier & $\begin{array}{l}\text { Partido } \\
\text { Popular }\end{array}$ & $\mathrm{M}$ & 1967 & working class & right wing & no \\
\hline $\begin{array}{l}\text { Candini, } \\
\text { Montserrat }\end{array}$ & CIU, PdCat & $\mathrm{F}$ & 1957 & $\begin{array}{c}\text { middle/upper } \\
\text { class }\end{array}$ & right wing & yes \\
\hline Chacón, Carme & PSC & $\mathrm{F}$ & 1971 & $\begin{array}{c}\text { middle/upper } \\
\text { class }\end{array}$ & left wing & no \\
\hline Colau, Ada & $\begin{array}{l}\text { Barcelona } \\
\text { en comú }\end{array}$ & $\mathrm{F}$ & 1974 & working class & left wing & no \\
\hline $\begin{array}{l}\text { Coscubiela, } \\
\text { Joan }\end{array}$ & $\begin{array}{l}\text { Iniciativa } \\
\text { per Catal. }\end{array}$ & M & 1954 & working class & left wing & no \\
\hline $\begin{array}{l}\text { Duran i Lleida, } \\
\text { Josep }\end{array}$ & $\mathrm{CIU}$ & $\bar{M}$ & 1952 & $\begin{array}{l}\text { middle/upper } \\
\text { class }\end{array}$ & right wing & yes \\
\hline $\begin{array}{l}\text { Forcadell, } \\
\text { Carme }\end{array}$ & $\begin{array}{l}\text { ANC, Esq. } \\
\text { Republ. }\end{array}$ & $\mathrm{F}$ & 1955 & working class & left wing & yes \\
\hline $\begin{array}{l}\text { Girauta, Juan } \\
\text { Carlos }\end{array}$ & Ciudadanos & $\mathrm{M}$ & 1961 & $\begin{array}{l}\text { middle/upper } \\
\text { class }\end{array}$ & right wing & no \\
\hline Herrera, Joan & $\begin{array}{l}\text { Iniciativa } \\
\text { per Catal. }\end{array}$ & $\mathrm{M}$ & 1971 & $\begin{array}{l}\text { middle/upper } \\
\text { class }\end{array}$ & left wing & no \\
\hline $\begin{array}{l}\text { Montserrat, } \\
\text { Dolors }\end{array}$ & $\begin{array}{l}\text { Partido } \\
\text { Popular }\end{array}$ & $\bar{F}$ & 1973 & $\begin{array}{l}\text { middle/upper } \\
\text { class }\end{array}$ & right wing & no \\
\hline Pascal, Marta & CIU, PdCat & $\mathrm{F}$ & 1983 & $\begin{array}{c}\text { middle/upper } \\
\text { class }\end{array}$ & right wing & yes \\
\hline Rivera, Albert & Ciudadanos & $\mathrm{M}$ & 1979 & $\begin{array}{l}\text { middle/upper } \\
\text { class }\end{array}$ & right wing & no \\
\hline
\end{tabular}




\begin{tabular}{|l|l|c|c|c|c|c|}
\hline Rovira, Marta & $\begin{array}{l}\text { Esquerra } \\
\text { Republ. }\end{array}$ & F & 1977 & working class & left wing & yes \\
\hline Sànchez, Jordi & $\begin{array}{l}\text { ANC, Junts } \\
\text { per Catal. }\end{array}$ & M & 1964 & working class & left wing & yes \\
\hline Tardà, Joan & $\begin{array}{l}\text { Esquerra } \\
\text { Republ. }\end{array}$ & M & 1953 & working class & left wing & yes \\
\hline Turull, Jordi & CIU, PdCat & M & 1965 & working class & right wing & yes \\
\hline
\end{tabular}


In addition to their key role in the sovereignty debate, other parameters were also taken into account in selecting the politicians. Firstly, based on their own testimony and family background, the public figures had to have a native command of the Catalan language, regardless of whether this language had later become their main instrument of personal communication. Some representatives, such as Carme Chacón, Albert Rivera and Josep Antoni Duran i Lleida, had Catalan as their mother tongue (in addition to Spanish, especially in the case of Chacón and Rivera), although their political trajectories, beyond the borders of Catalonia, has led to Spanish taking up a prominent place in their respective communicative repertoires. Even Joan Tardà, leader of the proindependence party Esquerra Republicana, and Joan Coscubiella and Joan Herrera, both from the leftist Iniciativa Per Catalunya, are regular users of Catalan, but all three have spent a number of years in the Spanish Parliament in Madrid, using the state language in their parliamentarian life. Conversely, the sample does not include other politicians who have come to play a significant role in the pro-sovereignty process, but whose less indigenous backgrounds would introduce a potential bias, thus making comparison more difficult. This is the case, for example, with politicians such as the leader of Ciudadanos in Catalonia, Inés Arrimadas, who was born in Jerez de la Frontera to parents originally from Salamanca. Although Arrimadas has a notable command of Catalan, it can be assumed that her expressive habits are somewhat further from the vernacular preferences of other politicians who were born in Catalonia and have a native command of Catalan. ${ }^{1}$

Secondly, the Spanish corpus has been built from a sample that was as balanced as possible in terms of the social parameters indicated in the table. Thus, from an ideological point of view, we have eight individuals linked to political parties considered to be right-wing or right-of-centre and the same number of left-wing or leftof-centre politicians. Likewise, we have a balanced representation of politicians affiliated with parties or coalitions considered as Catalan nationalists, on the one hand, and non-nationalists, on the other (for more details on the configuration of this predictor; see CODING below). Lastly, we also have a proportionate sample of representatives by gender (nine men and seven women).

\section{THE LINGUISTIC VARIABLES}

The Spanish linguistic variables analysed in this study are as follows. 
(a) the lateral consonant (-1) at the end of a word (as in fatal);

(b) the dental consonant (-d), also at the end of a word (as in virtud); and

(c) the production of this same consonant in an intervocalic position -ado(s) (as in pactado or mercados), which is the context where this consonant is subject to the greatest variation in the Spanish-speaking world.

\section{The variable (-l)}

In Spanish, the standard sound of the lateral consonant $/ 1 /$ is alveolar, although in certain syllabic contexts it resembles the point of articulation of other sounds (Hidalgo \& Quilis 2012:205). This is true for most Spanish dialects, although there is a notable exception in the varieties in contact with the Catalan language, where the transference of a velarised [1] is frequent (Hualde 2014:178; Davidson 2015:53-84). In fact, in Catalan, the phoneme $/ 1 /$ is realised as an alveolar lateral [1], although in the eastern and northwestern dialects, to which all the politicians in the sample belong, the pronunciation is often velarised (Fernández Planas 2011:161; Institut d'Estudis Catalans 2016:64). As concluded by Davidson (2015:262): "Even if a "Catalan-like" lateral is not used as a majority variant by any Spanish-dominant bilingual (in our sample, at least), the overall degree of lateral velarisation for Spanish-dominant bilinguals WAS SIGNIFICANTLY GREATER THAN THAT FOR SPANISH MONOLINGUALS FROM MADRID' (emphasis added).

In this study, I focus on the potential influence of the Catalan language on the variable in the coda position and, in particular, at the end of a word (especial). Nevertheless, the corpus occurrences of the definite article $e l$ have been excluded, together with the contractions $a l$ and $d e l$, as the extremely high frequency of these words in Spanish discourse could affect the representativeness of the data.

Only two Spanish variants of $/ 1 /$ are considered for the binary regression analysis. On the one hand, all of the alveolar forms are grouped together, apart from the specific articulatory nuances mentioned earlier. On the other hand, I also consider all of the velar pronunciations together, regardless of the degree of velarisation or the intensity and duration of the sound, which sometimes vary considerably from one speaker to another and even in the discourse of the same speaker (for more details on these different degrees of velarisation in current Catalonian Spanish, see Davidson 2015). 


\section{The variable (-d)}

In peninsular Spanish, the consonant / $\mathrm{d} /$ is a dental phoneme that has two main allophones depending on the phonological context: (a) a voiced occlusive, [d], at the beginning of a word following a pause and after nasal (donde) and lateral consonants (toldo); and (b) a voiced approximant [ð] in the remaining environments (Fernández Planas 2011:142-43; Hidalgo \& Quilis 2012:185-86). These contexts include the final position in a word, where the phonological neutralisation of the voiceless ( $\mathrm{t}$ )/voiced (d) dental pair has [ð] as the most prestigious form in careful speech [birtúð] (Alarcos 1981), although it alternates with other variants depending on a number of structural and sociolinguistic factors. Hualde (2014:140) claims that, in the Spanish spoken in Madrid, the elision of the [-d] is common in words with more than one syllable, but only before a pause or a word that begins with a consonant. Thus, in his opinion: 'in salud envidiable, there is no elision'. Nevertheless, he recognises that a recurring exception to this rule is that represented by the formal pronoun usted, 'which can have usté as a variant in all contexts'.

Moreover, this elision competes with other vernacular variants, such as the interdental $[\theta]$. Various studies have noted that, today, this pronunciation is among the most recognisable phonetic traits of central Spain (Estrada 2012; García Moutón \& Molina 2015; Molina 2016), and that Madrid is therefore in a zone of dialectal transition between the northern forms of speech, where the voiced dental and voiceless interdental forms coexist, and the southern forms, where the predominant tendency is towards elision (Molina 2016:348).

Lastly, we also have a voiceless variant of the consonant, [t], in some regions of South America, especially in emphatic contexts, but also in the varieties of Spanish in contact with Catalan (Hualde 2014:140). In fact, one difference between the two languages as regards this consonant occurs in the coda position, where Spanish has the voiced correlate, while Catalan makes it voiceless, unless the element that follows is voiced (Fernández Planas 2011:160-61; Institut d'Estudis Catalans 2016:69).

In the corpus, I have identified examples of the four Spanish variants mentioned above: voiceless dental [t], voiced dental [ð], elision [Ø] and interdental [ $\theta]$. In the study, I performed an independent regression analysis for two of them: (a) the voiced sound [ð], which is considered to be the standard and most prestigious form in the 
Spanish-speaking world; and (b) the voiceless dental allophone [t], which is the closest to the phonetics of Catalan.

\section{The variable (-ado)}

In intervocalic contexts, the greater weakness of the dental consonant with respect to other voiced fricative sounds explains why this variation has existed for so long (Lapesa 1968). Yet, although elisions have found their way into most intervocalic contexts, there is one particular context that has extended far beyond all others. This is the case of words ending in -ado(s) — both as a participle suffix (derrotado) and as another kind of ending (mercado, demasiado, etc.), where the dental consonant has been reported in the literature as having several phonetic alternatives: full voiced dental [d], dental approximant [ð], and elided [Ø] (Estrada 2012; García Moutón \& Molina 2015; Molina 2016).

In recent years, a number of studies have been published on this variable in peninsular Spanish, especially in the speech of the central-southern areas, although there are also examples of northern speech communities where elisions are very common (a summary of these works can be found in Samper 2011; Blas Arroyo 2019). However, the existence of a dialectal bastion has also been noted, where the elision of (-d) is not as common, namely, in the speech communities of the Catalan-speaking regions (Turell 1996; Blas Arroyo 2011, 2019). As argued elsewhere (Blas Arroyo 2007), the existence of points of structural similarity between the contexts in -ado and the parallel ones in -at of many words in Catalan (cantado/cantat, mercado/mercat, estado/estat) could account for the particular robustness of the dental consonant in these communities, and, furthermore, the fact that it is produced significantly more often among speakers with a greater command of Catalan.

\section{CODING}

Table 2 shows a summary of the factor groups considered in the analysis. Some of them are of a linguistic nature, previously addressed in studies of these linguistic variables in other contexts (see above). This is the case with the potential conditioning exerted by: the preceding vowel and consonant, the following phonetic context and different grammatical classifications of the words in which these variables appear. 
TABLE 2. Summary of the predictors and factors considered in the analysis.

\begin{tabular}{|c|c|c|c|c|}
\hline \multirow{2}{*}{ PREDICTORS } & \multirow[t]{2}{*}{ SHORT DESCRIPTION } & \multicolumn{3}{|c|}{ FACTORS } \\
\hline & & $-(1)$ & $-(d)$ & $-(d)-$ \\
\hline Previous vowel & $\begin{array}{l}\text { class of vowel that precedes the } \\
\text { variable }\end{array}$ & \multicolumn{2}{|c|}{$\begin{array}{l}\text { front }(\mathrm{e}, \mathrm{i}) \\
\text { nonfront vowels }(\mathrm{a}, \mathrm{o}, \mathrm{u})\end{array}$} & - \\
\hline Previous consonant & $\begin{array}{l}\text { first consonant of the syllable in which } \\
\text { the variable appears }\end{array}$ & $\begin{array}{l}\text { back consonant, } \\
/ 1 / \text {, other }\end{array}$ & $\begin{array}{c}{[\mathrm{t}]: \text { same, }} \\
\text { other } \\
{[\mathrm{d}]: \text { same, }} \\
\text { other }\end{array}$ & /d/, other \\
\hline Following context & $\begin{array}{l}\text { immediate phonic context that follows } \\
\text { the variable }\end{array}$ & $\begin{array}{l}\text { pause } \\
\text { consonant } \\
\text { vowel }\end{array}$ & $\begin{array}{l}\text { pause } \\
\text { voiceless } \\
\text { sound } \\
\text { voiced sound }\end{array}$ & $\begin{array}{l}\text { pause } \\
\text { dental } \\
\text { others }\end{array}$ \\
\hline $\begin{array}{l}\text { Grammatical } \\
\text { classification }\end{array}$ & $\begin{array}{l}\text { type of word according to different } \\
\text { gramatical criteria }\end{array}$ & $\begin{array}{l}\text { adjective } \\
\text { noun } \\
\text { other }\end{array}$ & $\begin{array}{l}\text { derived word } \\
\text { other }\end{array}$ & $\begin{array}{l}\text { participle } \\
\text { other }\end{array}$ \\
\hline Type of discourse & $\begin{array}{l}\text { speech events prototypically dialogic } \\
\text { (interviews, press conferences, talks, } \\
\text { debates) or monologic (parliamentary } \\
\text { interventions, institutional } \\
\text { declarations, rallies) }\end{array}$ & dialo & $\mathrm{ic} / \mathrm{monologic}$ & \\
\hline $\begin{array}{l}\text { Political } \\
\text { nationalism }\end{array}$ & $\begin{array}{l}\text { political orientation in the axis of } \\
\text { Catalanism }\end{array}$ & natio & alist, non-natio & halist \\
\hline Ideology & $\begin{array}{l}\text { political orientation in the right/left } \\
\text { wing axis }\end{array}$ & right & wing, left wing & \\
\hline Social origin & familiar social background & humb & le, other & \\
\hline Gender & gender & $\mathrm{F}, \mathrm{M}$ & & \\
\hline Age & year of birth & conti & uous factor & \\
\hline Year & year on which the discourse was held & conti & uous factor & \\
\hline Politician & name of the politician & rando & $\mathrm{m}$ factor & \\
\hline Word & word affected & rando & $\mathrm{m}$ factor & \\
\hline
\end{tabular}


At the extralinguistic level, I address the following factor groups.

Gender: In a stable situation of variation, the vernacular variants such as the velarisation of $(-1)$ or the devoicing of $(-d)$ are expected to a greater extent in male speech than in that of females; and the opposite are expected in the standard forms of that same (d). However, I also consider the possibility that changes favouring some of those variants are taking place, in which case women would lead them (Labov 2001; Queen 2013).

Year: With this predictor, I test the possibility that we are witnessing ongoing changes in some sense with the help of this continuous factor, which covers a period of eleven years, from 2007 to 2017.

Age: The generational factor is also a continuous factor and is measured on the basis of the politicians' year of birth. If there is a change favouring the vernacular or standard variants, this would be promoted mainly by the younger generations, which in the current sample are represented by politicians whose age is between thirty and forty years. Of course, these changes could run in the opposite direction, in which case we would find a greater presence of the corresponding variants among older politicians.

Social background: As far as this socialectal predictors is concerned, I do not take into account the educational level reached by the politicians at the time of speaking, since nearly all of them have university degrees (mainly in law and economics), ${ }^{2}$ but I do consider the socioeconomic level of their family background, and, therefore, the possibility that phonetic variation somehow reflects socioeconomic class. In this regard, it is expected that politicians from working class and humbler family settings lead the way in the more vernacular sounds, in contrast to individuals from wealthier backgrounds (middle/upper classes), who would be more inclined towards the standard variants.

Political ideology: On the political level, the members of the sample can also be divided into two groups. The group coded under the label Right includes politicians linked to what are traditionally considered as right-wing or right-of-centre parties (PP, Ciudadanos, CIU). Conversely, the members of the group Left range from the socialdemocrat options (Partit dels Socialistes de Catalunya, Esquerra Republicana) to more left-wing parties (Barcelona en Comú, Iniciativa Per Catalunya-Els Verds). The initial hypothesis is that the left-wing politicians promote the vernacular variants more than 
the right-wing ones, due to their traditionally closer link to the more popular sectors of society, where the pressures of covert prestige are more usual (Trudgill 1972).

Political nationalism: In Catalonia, however, this ideological affiliation intersects with another no less important one, which quite often even neutralises the right/left divide. Here I am referring to whether politicians and their corresponding parties are defined as Catalan nationalists or non-nationalists. ${ }^{3}$ As stated above, in recent times, Catalan nationalism is tightly entwined with the desire for independence, although there are exceptions, such as that represented in the corpus by Josep Antoni Duran i Lleida, who, after many years as a leading representative of Convergència I Unió in the Spanish parliament, abandoned his political career and dissociated himself from the pro-independence strategy defended by his one-time coalition partners. Moreover, not all the politicians defined as non-nationalists are insensitive to some of the historical claims of Catalanism, such as the 'right to decide' in a legal referendum agreed to with the Spanish government (Colau, Coscubiela, Herrera).

Type of discourse: This predictor is based on the prototypical dialogic or monologic nature of the communicative act in which the politician is taking part. The dialogic communicative acts in the corpus include interviews, press conferences, talks, and debates, while the monologic ones include parliamentary interventions, institutional declarations, rallies, and so on. From a classic perspective on style (Labov 1972), the greater degree of attention that the speaker pays towards his or her own speech in the second group of communicative events could be expected to have a negative effect on the vernacular variants. Yet, I also take into account the theory of accommodation (Giles, Coupland, \& Coupland 1991), according to which we could expect greater instances of convergence (or divergence) with respect to the articulatory habits of the interlocutor in dialogic acts.

Lastly, the study takes into account two other factor groups, which, unlike the previous ones, I consider to be random in a mixed-effects logistic regression analysis. In this way, the real incidence of the predictors considered is tested following an exhaustive examination of them within each of the words and the politicians who used them. Consequently, this enables us to test the variability not only across social groups but also within the idiolects themselves, as well as within the words where the linguistic variables appear. 


\section{METHODOLOGY}

To conduct the study, a corpus was created by collecting videos featuring the politicians on a number of internet sites, such as Youtube, several online Spanish media sites, the Spanish and Catalan Parliaments online web pages, and so on. To make the comparative analysis easier, I built up a sample of speech lasting about an hour for each politician, consisting of different communicative acts like those mentioned above (interviews parliamentary interventions, rallies, press conferences, institutional declarations, etc.), all of them represented by a similar amount of speech. There is also a balanced representation of the years covered by the sample, which, as stated above, ranges from 2007 to 2017.

All of the samples of speech were transcribed using the Voice Typing tool in Google Docs, the initial versions of which were subsequently reviewed and edited manually. A concordance program (Wordsmith v. 6.0) was then used to obtain all of the occurrences of the linguistic variables, and their written transcriptions were checked perceptually against the oral samples by two raters. In a few cases (less than 7\%), where there was no match between the raters, the corresponding examples were subjected to an additional analysis using Praat (Boersma \& Weenink 2006).

For the quantitative analysis I performed a mixed-effect logistic regression analysis, which deals with fixed categorical factor groups (sex, social background, preceding vowel, etc.) as well as others of a continuous (year, age) and random nature (word, politician). For that purpose, I used Rbrul (Johnson 2009), which allows access to three fundamental measures of a variationist study, namely: (a) the identity of the predictors independently selected (and not selected) as significant; (b) the factor weight of every factor into which the selected predictors are divided; and (c) the explanatory direction in which these run, which is especially useful for the contrastive analysis.

\section{RESULTS}

The following sections analyse the data derived from the logistic regression analysis carried out for each variable. Due to space restraints, here I do not provide the reader with all of the details that would be relevant for a more thorough examination of the data; rather, I present the features more pertinent to a comparative analysis, which is the main aim of this study. 


\section{The variable (-l)}

The variable yielded 1,759 tokens, of which $44 \%(n=773)$ are velarised variants and $56 \%(n=986)$ are alveolar sounds. Although the latter variants, which represent the standard pronunciation in Spanish, are more frequent, the number of vernacular forms is undeniably high.

Velarisation is, however, unequally distributed among the different members of the sample, as shown by the data in Figure 1.

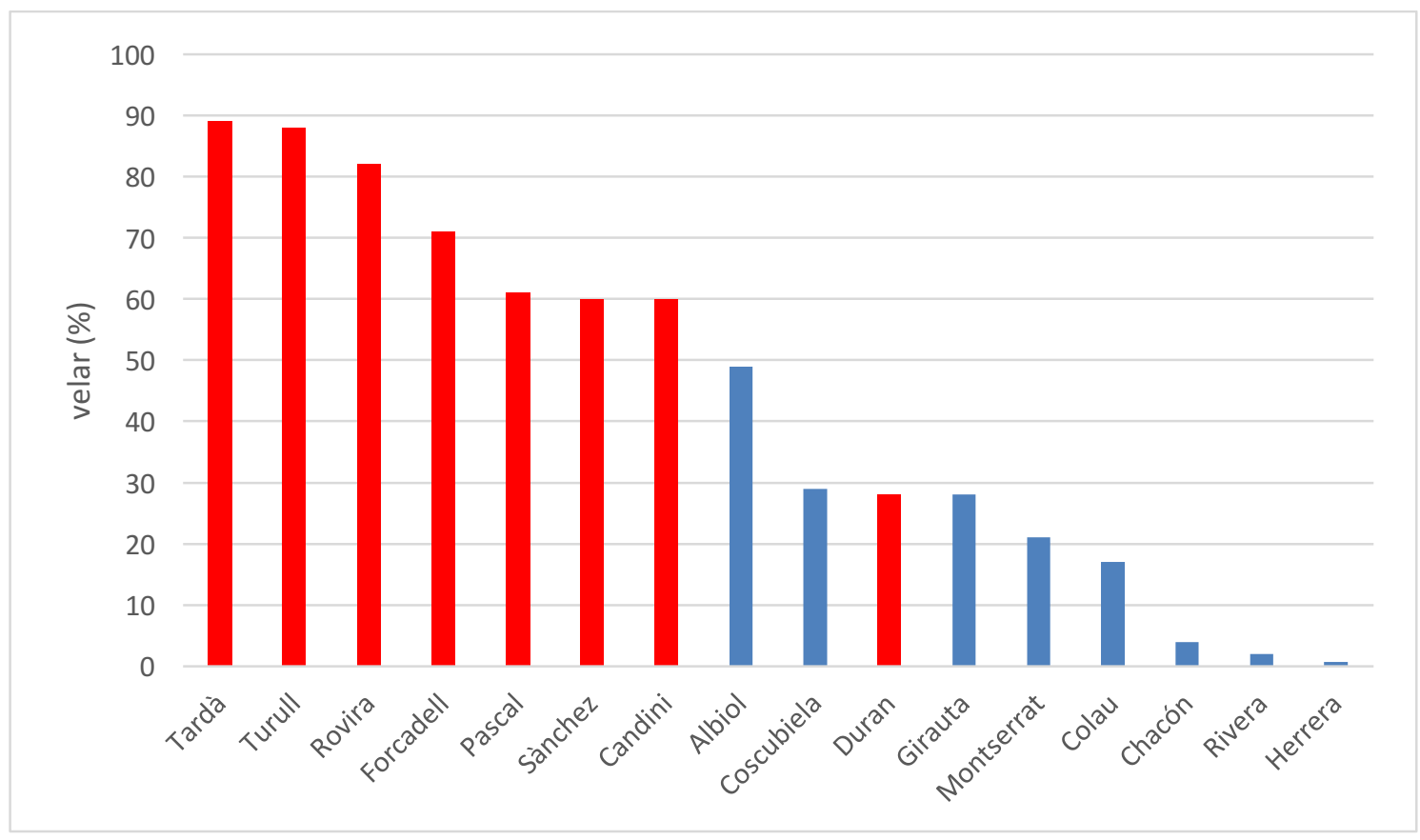

FIGURE 1. Distribution of the velar variants of (-1) by politicians (\%). The politicians of the Nationalist group are highlighted in red, while the non-Nationalist are highlighted in blue (the same criterion is used in Figures 3, 4, and 5).

Together with individuals who nearly always velarise (the cases of Tardà, Turull, and Rovira, with percentages above $80 \%$ ), there are others who hardly ever do so, some of the most notable cases in this respect being the ex-socialist minister Carme Chacón, the leader of Ciudadanos, Albert Rivera, and the former representative of Iniciativa per Catalunya-Verds, Joan Herrera, for whom I found only one occurrence of the vernacular variant out of a total of 130 . The other politicians stand midway between these two extremes, with varying rates of velarisation. 
The mixed effects logistic regression analysis performed shows only four predictors as significant, due to their solid and independent contribution to the variation of $(-1)$ (see Table 3$)$.

TABLE 3. Contribution of the selected factor groups according to the mixed-effects logistic regression analysis to the choice of velar [-1] (Rbrul) (Random variables: words, politicians).

\begin{tabular}{|c|c|c|c|c|c|}
\hline & $\mathrm{N}$ & TOTAL $\sum$ & $\%$ & LOG-ODDS & FW \\
\hline \multicolumn{6}{|l|}{ PREVIOUS VOWEL } \\
\hline Front & 63 & 314 & 20 & -1.00 & .27 \\
\hline Nonfront & 710 & 1445 & 49 & 1.00 & .73 \\
\hline Range & & & & & 46 \\
\hline \multicolumn{6}{|c|}{ FOLLOWING CONTEXT } \\
\hline Pause & 391 & 764 & 51 & 0.36 & .59 \\
\hline Other & 382 & 995 & 38 & -0.36 & .41 \\
\hline Range & & & & & 18 \\
\hline \multicolumn{6}{|c|}{ POLITICAL NATIONALISM } \\
\hline Nationalists & 619 & 902 & 69 & 1.308 & .78 \\
\hline Non-nationalist & 154 & 857 & 18 & -1.308 & .21 \\
\hline Range & & & & & 57 \\
\hline \multicolumn{6}{|l|}{ SOCIAL ORIGIN } \\
\hline Humble & 563 & 894 & 63 & 0.878 & .70 \\
\hline Other & 210 & 865 & 24 & -0.878 & .29 \\
\hline Range & & & & & 41 \\
\hline
\end{tabular}

n (1759), intercept (-1.161), overall proportion (0.44), log.likelihood (-762.894), AICc (1539.853), Dxy.total (0.77)

On the structural level, the hypothesis about the incidence of the preceding vocalic context in the realisation of the variable is confirmed. The front vowels $(/ \mathrm{e} /, / \mathrm{i} /)$ are by far the ones that give rise to fewer velarisations $(.27 ; 20 \%)$. These are in opposition to the nonfront vowels $(/ \mathrm{a} /, / \mathrm{o} /, / \mathrm{u} /)$, whose contribution to the vernacular pronunciation of (1) is much higher $(.73 ; 49 \%)$.

The same occurs with the second structural predictor, whose figures also display significant differences. Nevertheless, the regression analysis only yields differences between the favourable prepausal contexts $(.59 ; 51 \%)$ and the rest - consonantal and vocalic - as significant, whose joint contribution to velarisations is moderately negative $(.41 ; 38 \%)$. 
Moreover, two particularly robust extralinguistic factor groups can be seen. The first is social origin of the individuals, which distinguishes between those who come from a lower socio-economic class and those who do not. As expected, the former are the ones who favour velarisations most clearly $(.70 ; 63 \%)$, in contrast to the behaviour of the latter $(.29 ; 24 \%)$, which are much closer to the standard.

Yet, even more notable are the differences between the two groups formed on the basis of their orientation towards political Catalanism. The politicians who make up the nationalist group achieved the highest factor weight of the whole analysis (.78; $69 \%)$, a long way ahead of the non-nationalists $(.21 ; 18 \%)$.

However, neither sex nor age, which according to Davidson (2015:137) play an important role in mediating this phenomenon in his sample of Catalan (nonpolitician) speakers, achieves any relevance in our study.

\section{The variable (-d)}

General results. In the corpus, 1,691 tokens of the variable were extracted, the majority of which correspond to the standard variant [ð], 38\% $(n=652)$, closely followed by elisions [Ø], 35\% $(n=598)$, and somewhat further behind by the voiceless dental [t], $19 \%(n=325)$, and the interdental $[\theta], 8 \%(n=116)$.

These data clearly contrast with those of other varieties. In a recent study conducted on the wealthy district of Salamanca in Madrid, Molina (2016:351) offers figures for elisions that exceed $60 \%$ - practically twice as many as in the sample analysed in this study. In contrast, voiced dental sounds are only slightly higher than $20 \%$ in this district of Madrid, also at a distance from their occurrence in the Catalan politician sample, which practically doubles such percentages. Conversely, the figures of the interdental forms (the least frequent in both corpora) are closer to each other, although those found in the Madrid sample (15\%) exceed again those from the Catalan corpus $(8 \%)$.

Returning to the latter, Figure 2 now offers the distribution of these variants by individuals, showing considerable intra-dialectal variation. Eight out of the sixteen individuals display instances of all the variants, while the other eight exhibit some restriction (Albiol, Candini, Coscubiela, Forcadell, Pascal, Rovira, Sànchez, Turull). None of the members of the latter group include the interdental variant $[\theta]$ in their repertories, which is not by chance the least indigenous form of all those considered in 
the analysis (see above ). ${ }^{4}$ In addition, politicians such as Albiol do not produce any elision, closely followed by Forcadell, with only $4 \%(n=3)$ of zero variants.

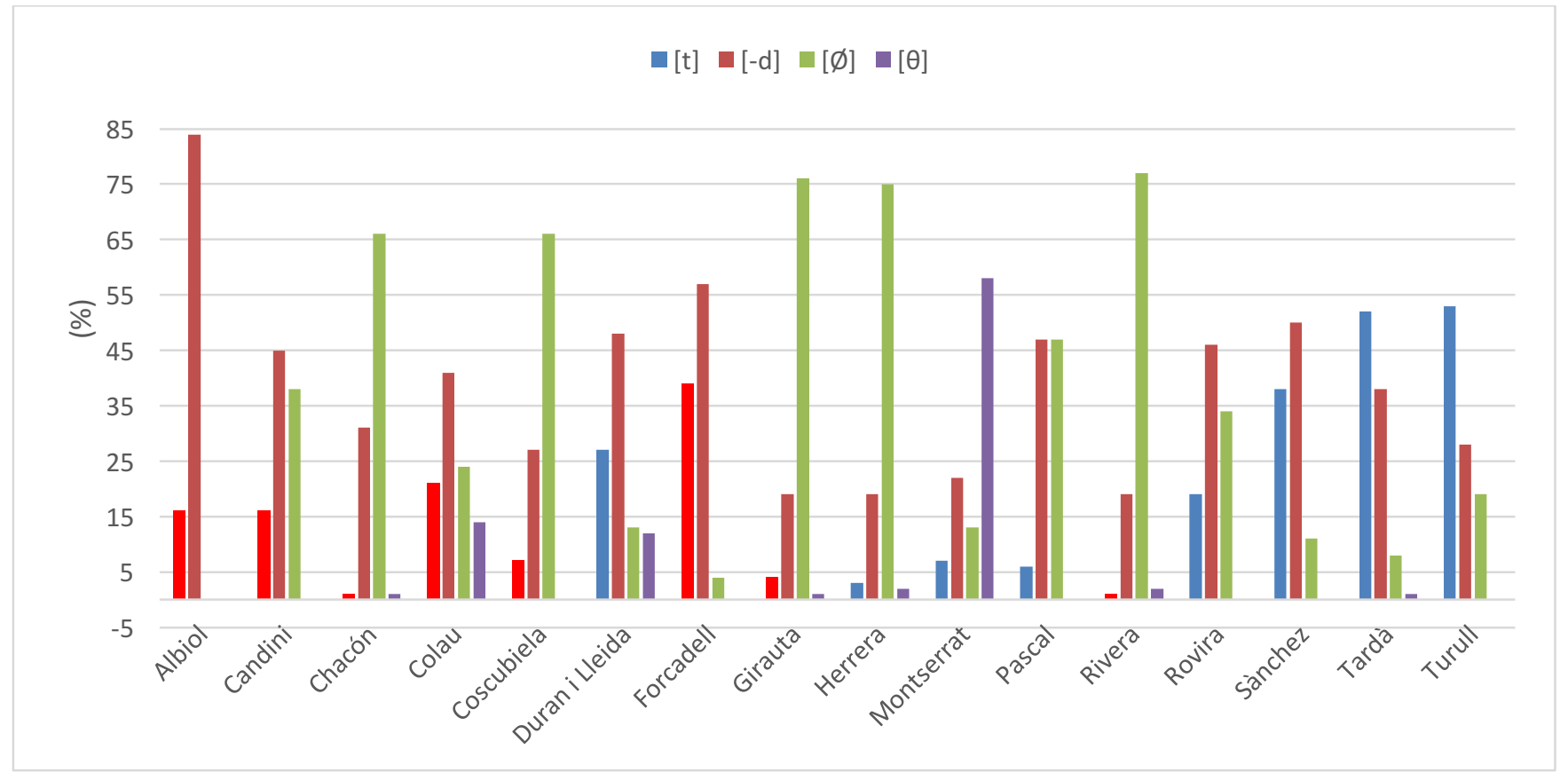

FIGURE 2. Distribution of the variants of (-d) by politicians.

These elisions are, together with the standard variant [ð], the most frequent forms for most of the individuals in the sample, although the distribution from one to another is unequal. Politicians such as Rivera, Girauta, Herrera, Chacón, and Coscubiela are mostly inclined towards elisions. In contrast, others, such as Candini, Colau, Duran, Forcadell, Rovira, and Sànchez, use the voiced dental variant [ð] more often.

The variant [t]. Despite the foregoing, there are also some notable exceptions to this pattern which affects the voiceless dental $[\mathrm{t}]$, the most vernacular variant, the distribution of which is shown in Figure 3. This figure shows the existence not only of great variability in the use of this pronunciation by the Catalan politicians, but also the presence of some speakers who take its use far beyond the average rate of use, as is the case of Turull, Tardà, Forcadell, and Sànchez. 


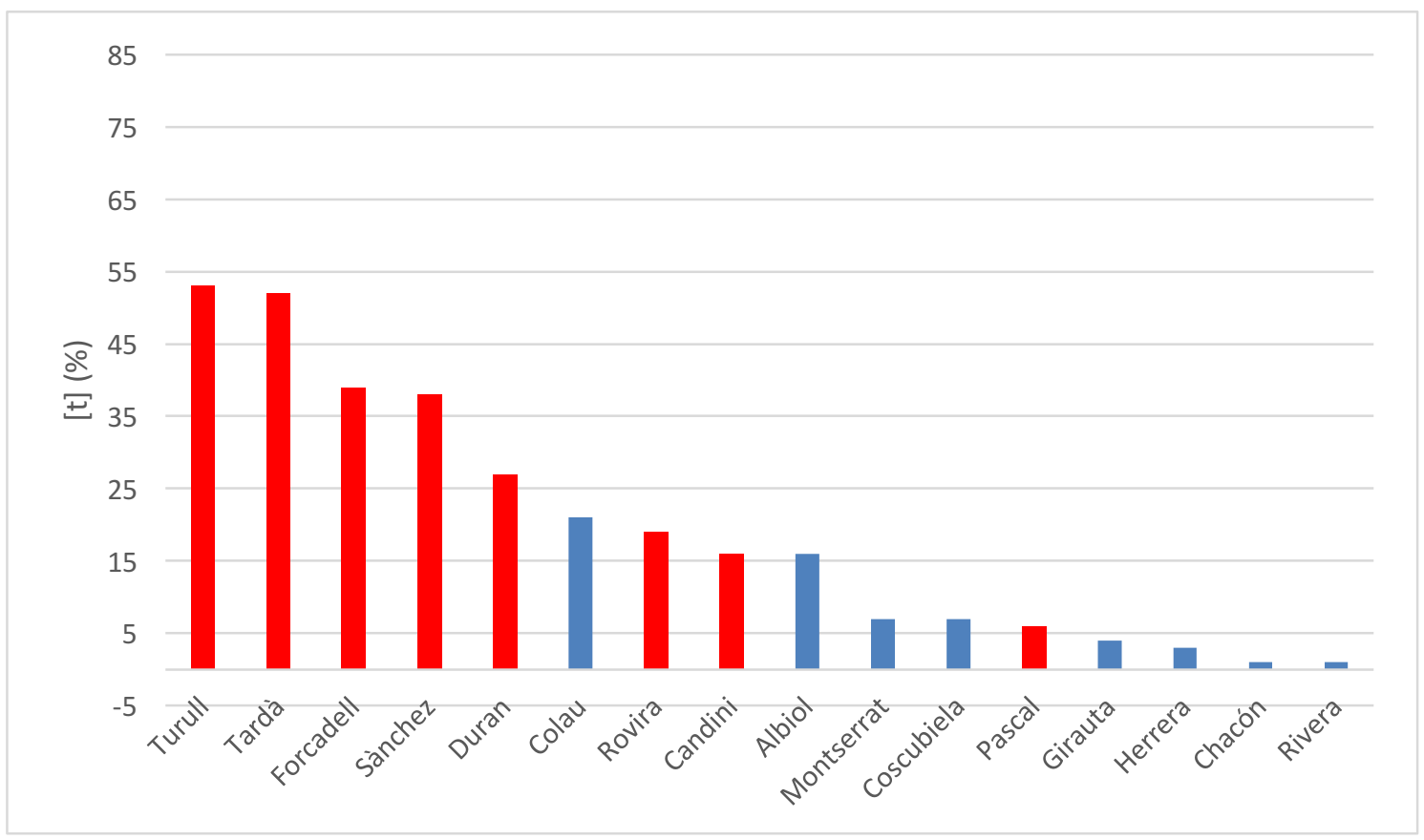

FIGURE 3. Distribution of the voiceless dental [t] by politicians (\%).

After the joint analysis of all of the factor groups considered in the study, only three predictors contribute in an independent and significant way to explain the selection of $[\mathrm{t}]$ (see Table 4). Of these, the first is linguistic, and confirms the incidence favouring the vernacular form when the consonant is preceded in the same syllable by another voiceless dental sound (magnitud, lealtad, voluntad, etc.; .75; 37\%). And, as regards the sociological predictors, the regression model only grants sufficiently robust and independent significance to the differences considered earlier when discussing (-1). On the one hand, the fact that the voiceless dental is especially favoured by politicians from working class family settings $(.68 ; 32 \%)$ is confirmed. On the other hand, that same explanatory power is granted to the nationalist politicians, whose use of the vernacular variant is, as a whole, significantly higher $(.68 ; 33 \%)$ than among the nonnationalists $(.32 ; 8 \%)$. None of the other factors, whether linguistic or extralinguistic, play a sufficiently relevant role to explain the variation.

TABLE 4. Contribution of the selected factor groups according to the mixed-effects logistic regression analysis to the choice of the voiceless dental [-t] (Rbrul) (Random variables: words, politicians).

\begin{tabular}{|l|l|c|c|c|c|}
\hline & $\mathrm{N}$ & TOTAL $\sum$ & $\%$ & LOG-ODDS & FW \\
\hline
\end{tabular}




\begin{tabular}{|l|c|c|c|c|c|}
\hline PREVIOUS CONSONANT & & & & & \\
\hline /t/ & 172 & 461 & 37 & 1.141 & .75 \\
\hline Other & 153 & 1230 & 12 & -1.141 & .24 \\
\hline Range & & & & & 51 \\
\hline NATIONALISM & & & & & .68 \\
\hline Nationalist & 265 & 830 & 32 & 0.738 & .32 \\
\hline No & 60 & 861 & 7 & -0.738 & 36 \\
\hline Range & & & & & .68 \\
\hline SocIAL ORIGIN & & & & & .32 \\
\hline Humble & 245 & 745 & 33 & 0.772 & 36 \\
\hline Other & 80 & 946 & 8 & -0.772 & $(1216.413)$ \\
\hline Range & & & & & . \\
\hline
\end{tabular}

n (1691), intercept (-1.437), overall proportion (0.19), log.likelihood (-600.164), AICc (1216.413), Dxy.total (.78)

The variant [-ð]. I now analyse the case of the standard variant, the voiced approximant allophone [ð], which leads the ranking of uses in the sample as a whole, with a figure of $38 \%$.

The distribution by politicians can be seen graphically in Figure 4. First place is occupied by the leader of the Partido Popular, Xavier Albiol, with very high proportions (84\%), followed some way behind by representatives of other parties such as Forcadell, Sànchez, Duran, Pascal, Rovira, and Candini, with figures close to or slightly higher than $50 \%$.

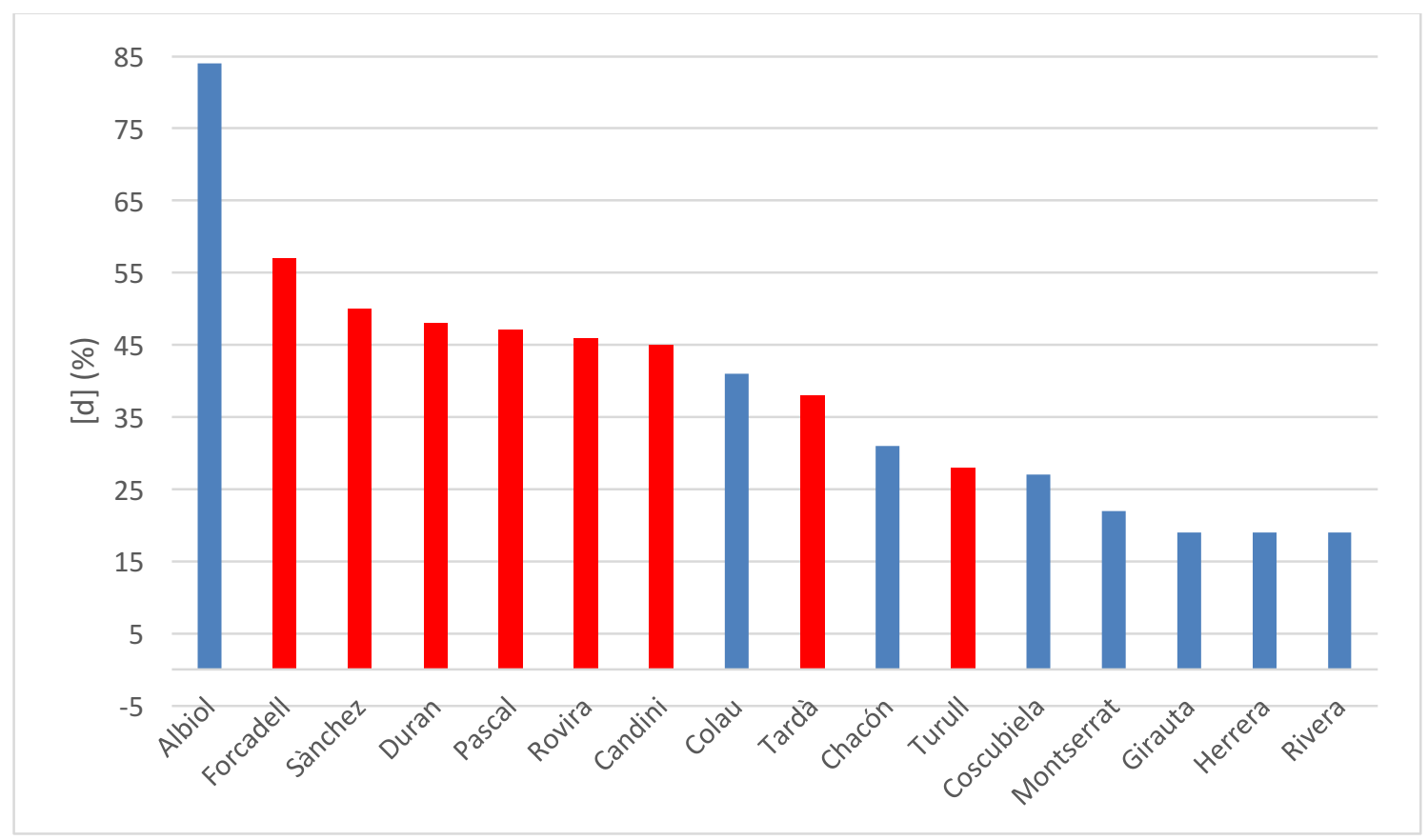


FIGURE 4. Distribution of [-ð] by politicians (\%).

The particular case of Albiol, a representative of a right-wing non-nationalist party (see more details in the DISCUSSION), does not stop the factor Nationalism from being newly selected as significant by Rbrul, again with the nationalist group favouring the variant $(.60 ; 45 \%)$, as opposed to the non-nationalist group, whose contribution is negative $(.39 ; 32 \%$; see Table 6$)$. In fact, the anomalous figures for the leader of the Partido Popular (whose variationist profile is analysed later on; see the DISCUSSION) contrast strongly with those of the other non-nationalist politicians, who stand in the last positions on the axis described in Figure 4.

Nevertheless, some differences can be seen with respect to what was noted earlier for the vernacular variant [t]. On the one hand, the factor weight of the nationalist group was higher then (.68) than now (.60). On the other hand, the predictor Nationalism is now the only one selected in the social matrix by the logistic regression model (Table 5), unlike [t], in which it was accompanied by the politicians' social origin. As can be seen in Figure 4, politicians from both lower socioeconomic classes (Albiol, Forcadell, Sànchez) and higher ones (Duran, Pascal, Candini) play a part in favouring the voiced approximant [ð]. And the same occurs among politicians who favour the variant to a lesser extent: some come from the working classes (Turull, Coscubiela), while others are from wealthier social groups (Montserrat, Girauta, Rivera).

TABLE 5. Contribution of the selected factor groups according to the mixed-effects logistic regression analysis to the choice of [-ð] (Rbrul) (Random variables: words, politicians).

\begin{tabular}{|l|c|c|c|c|c|}
\hline & $\mathrm{N}$ & TOTAL $\sum$ & $\%$ & LOG-ODDS & FW \\
\hline PREVIOUS CONSONANT & & & & & \\
\hline$/ \mathrm{d} /$ & 557 & 1230 & 45 & 0.883 & .70 \\
\hline Other & 95 & 461 & 21 & -0.883 & .30 \\
\hline Range & & & & & 40 \\
\hline FOLLOWING CONTEXT & & & & & \\
\hline Dental & 158 & 326 & 48 & 0.510 & .62 \\
\hline Other & 350 & 889 & 39 & 0.071 & .52 \\
\hline Pause & 144 & 476 & 30 & -0581 & .36 \\
\hline Range & & & & & 26 \\
\hline
\end{tabular}




\begin{tabular}{|l|c|c|c|c|c|}
\hline PolitiCAL NATIONALISM & & & & & \\
\hline Nationalists & 376 & 830 & 45 & 0.42 & .60 \\
\hline Non-nationalist & 276 & 861 & 32 & -0.42 & .39 \\
\hline Range & & & & 21 \\
\hline
\end{tabular}

Another difference with respect to [t] is the greater relevance found by structural factors. If on that occasion only the previous consonant was shown to be significant, this predictor is now accompanied by another linguistic factor: the following phonetic context. Thus, the presence of another dental consonant both in the following (.62; $48 \%)$ and the preceding contexts $(.70 ; 45 \%)$ favours the appearance of [ð].

\section{The variable (-ado-)}

Figure 5 shows an overwhelming choice of the full variant [aðo] by most of the individuals in the sample, which is significantly higher than the figure found in previous studies in Catalan speech communities (Turell 1996: 86\%; Blas Arroyo 2007: 54\%). Of the 1,842 tokens found in the corpus, only $113(6 \%)$ correspond to the elided variant [ao], whereas the other 1,729 are examples of the full form [aðo] (94\%). Leading the way in these cases, I find a list of five individuals, with categorical uses of the [aðo] variant (Candini, Chacón, Forcadell, Sànchez, and Turull), followed closely behind by other with quasicategorical proportions (Albiol, Colau, Pascal, Tardà, and Rovira). Some way behind, although with figures close to $90 \%$, other politicians are also found (Coscubiela, Duran, Girauta, and Montserrat). The only exception is the leader of the Ciudadanos party, Albert Rivera, who again appears in the last positions in the graph (49\%), although this time clearly alone. 


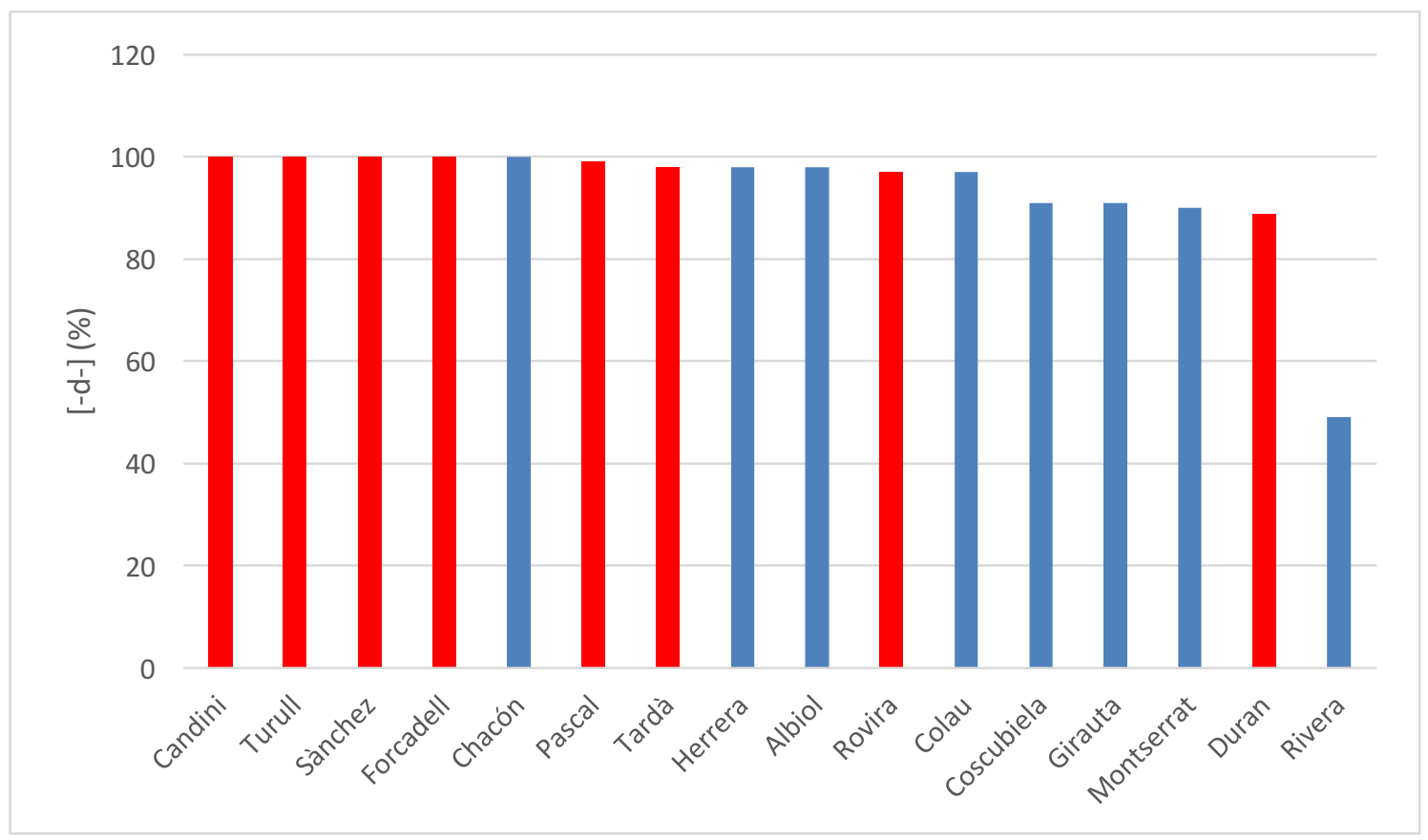

FIGURE 5. Distribution of [-d-] by politicians (\%).

In spite of the greater uniformity of these results, the Nationalism factor group is again being selected as significant by the mixed effects logistic regression analysis. As shown in Table 6, only fifteen (not even $2 \%$ ) of the 847 tokens of the variable found among the nationalist group correspond to variants other than [ð]. Among the nonnationalists, the overall figures of the standard variant are also very high, but significantly less so than among the nationalists. The greatest responsibility in these figures belongs to the above mentioned Albert Rivera, with fifty-two elisions (of the ninety-eight in this group), followed some way behind by other representatives of nonnationalist parties, such as Montserrat $(n=16)$, Girauta $(n=11)$ and Coscubiela $(n=9)$.

Apart from that extralinguistic factor group, the variation of (-d-) is also conditioned by the phonetic context following words ending in -ado and, albeit to a lesser extent, by the grammatical category of these words. As regards the first, prepausal contexts are the ones that favour the retention of the $(-\mathrm{d})$ the most $(.78 ; 98 \%)$. Finally, the standard pronunciation is also more resistant in grammatical categories other than the verb participle, such as nouns (mercado), adjectives (refugiado), or adverbs (demasiado). In contrast, slightly higher instances of elision are observed in the participles. 
TABLE 6. Contribution of the selected factor groups according to the mixed-effects logistic regression analysis to the choice of [-ð-] in the -ado(s) word final contexts (Rbrul) (Random variables: words, politicians).

\begin{tabular}{|l|c|c|c|c|c|}
\hline & $\mathrm{N}$ & TOTAL $\sum$ & $\%$ & LOG-ODDS & FW \\
\hline GRAMMATICAL CLASS & & & & & \\
\hline Participle & 739 & 810 & 91 & -0.413 & .40 \\
\hline Other & 990 & 1032 & 96 & 0.413 & .60 \\
\hline Range & & & & & 20 \\
\hline FolLOwING CONTEXT & & & & & \\
\hline Pause & 553 & 563 & 98 & 1.296 & .78 \\
\hline Dental & 183 & 204 & 89 & -0.955 & .28 \\
\hline Other & 993 & 1075 & 92 & -0.340 & .42 \\
\hline Range & & & & & 50 \\
\hline PoLITICAL NATIONALISM & & & & & .74 \\
\hline Nationalists & 832 & 847 & 98 & 1.039 & .26 \\
\hline Non-nationalist & 897 & 995 & 90 & -1.039 & 48 \\
\hline Range & & & & & \\
\hline
\end{tabular}

n (1842), intercept (4.612), overall proportion (.93), log.likelihood (-295.163), AICc (604.387), Dxy.total $(.87)$

\section{DISCUSSION}

Using comparative sociolinguistic tools, in the previous pages I have analysed four phonetic variants in a population sample made up of sixteen leading politicians in the current Catalan prosovereignty procés. As stated above, one important difference in those variants is that two of them - the velarisation of (-1) and the devoicing of (-d)are vernacular forms, which are associated with Catalan stereotypes, and which can only achieve some kind of covert prestige within these speech communities. In contrast, the next two - the voiced dental pronunciation of the (d) both at the end of a word and in the intervocalic settings of -ado-are the standard variants of their respective variables, and therefore those which convey overt sociolinguistic prestige in the entire Spanishspeaking world.

On the structural plane, I have shown how the more relevant predictors were those that involve the preceding or the following phonetic context of the variable. As regards (-1), I found that velarisations are significantly greater with nonfront vowels (/a/, $/ \mathrm{o} /, / \mathrm{u} /)$ than with the front ones $(/ \mathrm{e} /, / \mathrm{i} /)$, consistent with the pronunciation of Catalan. Similarly, the preceding consonant is significant in promoting the voiceless $[t]$ and the 
voiced dental variants [ð]: both are favoured when the final syllable of the word begins with /t/ and /d/, respectively. Likewise, I have shown the relevance of the following phonetic context in three of the four variants analysed, although with different patterns in each case.

The same occurs on the extralinguistic plane, where the initial hypotheses posited the potential role of certain classic factors in the study of phonetic variation. Yet, politicians' gender does not play a significant role in conditioning any variable; and the same is true of the continuous factors considered (year of discourse and age) with which I aimed to determine the existence of potential change trends within the community. To the contrary, we find great stability. Likewise, ideology on the right/left axis has not behaved as expected or, in fact, how it has been noted in studies conducted in other countries (e.g. Hall-Lew et al. 2010; Schrimpf 2013; Knoblock 2014; Hall-Lew et al. 2017, among others). Among the Catalan politicians, this constraint does not explain any of the variation phenomena considered in the study. Finally, expectations about potential differences according to the different types of discourse considered in the study have not been fulfilled either. Thus, the division between more prototypically dialogic or monologic political genres does not explain anything relevant regarding the variables considered here.

In practice, the only two factors that surpass the threshold of significance are the politicians' social origin and their ideological orientation regarding Catalan nationalism. Nevertheless, there is an important difference between the two: their scope. Indeed, the politicians' social background is only selected to explain two vernacular variants: the velarisation of $(-1)$ and the voiceless [ $\mathrm{t}$ ] at the end of a word. In both cases - in accordance with the initial premises - the variation is associated with the working-class origins of the representatives, who stand above the rest of politicians in the uses of the more vernacular sounds. In addition, these uses seem to be stable over time, given the lack of sensitivity of the generational predictor pointed out earlier. However, this same pattern is not produced with the other two variants, [-ð] and [-ð-].

The foregoing does not occur, however, with the predictor Catalan Nationalism, which in practice is the only one that appears systematically selected to explain all the variation analysed in this study. In this sense, we have seen how nationalist politicians, but especially those with an openly pro-independence orientation (an exception being that represented by Duran I Lleida, whose particular profile is interpreted below), 
clearly favour the two vernacular variants analysed, but also those in which prestige has a more canonical and pan-Hispanic scope.

How can these results be explained? As I see it, the explanation could lie in the social meanings conveyed by these variants. As stated by Eckert (2012), one of the characteristics of linguistic variables is that their social significance takes on specific meanings in the different stylistic contexts in which they are used, and these meanings can be grouped around a certain indexical field. In the case we are addressing here, that indexical field seems to be tied to the idea of authenticity. For Catalan nationalists (particularly, independentists), that authenticity initially revolves around the preferredeven exclusive - use of the Catalan language, considered to be the only language Catalonia must claim as its own. Hence, faced with the 'obligation' to speak the other language (Spanish), which is still official and spoken by many social agents (journalists, judges, non-Catalan politicians, etc.), the pro-independence politicians 'appropriate' the Spanish language by tingeing its expressive habits, either:

(a) with clearly vernacular features that are obvious calques of Catalan phonetics (the velarisation of (-1) and the devoicing of (-d)), or

(b) with other sounds that, despite coinciding this time with the prestige forms in the rest of the Spanish-speaking world, are also the ones that are structurally closer to the indigenous articulatory uses.

It therefore comes as no surprise to find, for example, how the vast majority of these politicians alternate between the (vernacular) voiceless [t] and (standard) voiced [ð] variants of the final (-d), but include in their speech very few examples of forms that are more characteristic of other regional varieties of peninsular Spanish, such as the typically Castilian interdentalisation $[\theta]$.

In contrast, the rules of the non-nationalist politicians (both right- and left-wing) appear to be far more variable, and so:

(a) they stand, with the odd exception, at the far end of the more vernacular variants; and

(b) they allow a wider variety of allophones to enter into their corresponding idiolects, including variants that are more frequent in other dialects of peninsular Spanish. 
Some representative cases of this position are right-wing politicians, like Montserrat, who stands out above the rest with her anomalous uses of the interdental $[\theta]$, or Rivera, who always ranks between last and second-last on the corresponding lists; but the same happens with some left-wing representatives, such as Herrera, Coscubiela, or Chacón. Ada Colau generally stands halfway between the two extremes, which, linguistically speaking, would represent a certain degree of iconisation of the political stance taken by the mayor of Barcelona, whose political postures often try to maintain an ambiguous balance between the two worlds that clash with one another in the Catalonia of the procés.

Within this framework, two politicians display a behaviour that is more particular and different from the practices noted above. The first is on the nationalist side and is Josep Antoni Duran i Lleida. One important difference between him and his fellow party members is that, with the exception of the variants of $(-d)$, the former representative of Catalan nationalism in the Spanish Parliament is not in the first position (rather, quite to the contrary) in either of the other two: neither the velarisations of (-1), in which he is even surpassed by some non-nationalist politicians, nor in the uses of the dental consonant in words ending in -ado, where he ranks second-last.

Could this be a new case of iconisation, of the distancing of this politician with respect to his fellow party members, disillusioned as he has claimed to be on a number of occasions by the pro-independence direction in which they have led Catalonia? Some telling data could favour this hypothesis. In the case of the velarisation of (-1), Duran is the only politician who displays a downward tendency in the uses of the variant between 2007 and 2017 (2007: 40\% $(n=47)$; 2013: 37\% $(n=8) ; 2015: 14 \%(n=21)$; 2017: $12 \%(n=25))$. And the same occurs with the variant [t] $(2007: 44 \%(n=54)$; 2013: $21 \%(n=34) ; 2015: 12 \%(n=35) ; 2017: 13 \%(n=15))$. Likewise, although the interdental $[\theta]$ is not very frequent in his idiolect $(12 \%)$, the fact that all instances of it ( $n=17)$ were produced during the last year (2017) is telling, as this is when he had broken all ties with his fellow party members. Moreover, all instances occur (not accidentally?) in an interview with Carlos Herrera, a leading representative of the rightwing media and a devoted antinationalist, and thus in a potential place for linguistic accommodation.

Another particular case is that of the leader of the Partido Popular, Xavier Albiol. He not only ranks amongst the highest in terms of the vernacular uses in the non-nationalist ranks, but also leads the standard ones; in this respect, his overwhelming 
uses of the voiced dental of both (-d) and (-d-) are especially striking. From a working class background, the Catalan origin of Albiol's speech becomes immediately apparent. Not only does he usually speak Catalan, but also, when speaking Spanish, he tinges his speech with sounds that are familiar to his audience: (a) he often velarises the (1) (also in other positions not taken into account in the study); (b) in the pronunciation of the final (-d) he avoids the more characteristic pronunciations of other peninsular varieties [berdá, berdá $\theta$ ]; and (c) he commonly sprinkles his speech with a number of calques from Catalan ('cualquier mínimo movimiento no tan solo por parte de los responsables de los Mossos d'Esquadra'; 'a labrarse un futuro a tirar hacia delante') together with convergence phenomena such as using the plural form of existential haber ('habian, pues, 700 u 800 personas').

Thus, for the Partido Popular - the polar opposite of Catalan nationalismAlbiol represents a valuable indigenous asset, at a distance from the traditionally wealthier and Spanish nationalism bases of the conservative party. Ultimately, then, this non-nationalist politician is constructing a set of social meanings whose backdrop is the same indexical field discussed earlier, although with a different interpretation: if for the Catalanist (pro-independence) politicians the variation according to some indigenous norms is the way of 'appropriating' a 'foreign' language, for the leader of the Partido Popular it would be an emblem of the fusion of two identities that should be complementary and not in confrontation: the Spanish and the Catalan.

\section{CONCLUSIONS}

In recent years, the analysis of the agentive nature of variation has become increasingly more prominent in sociolinguistics, since it is assumed that variation does not simply reflect, but also constructs social meanings. In this work, I have analysed some examples of this agentivity among a group of politicians during the current Catalan proindependence procés. Based on the analysis of several phonetic variables in Spanish, we have verified that diverse traditional extralinguistic factors, such as sex, age, the temporal axis, or the right/left political opposition, do not contribute anything relevant to explain the variation. Even the degree of exposure to Catalan is not sufficient to account for the remarkable uniformity among politicians who have carried out their activity either inside or outside Catalonia, and in many cases in both places. Only the 
social background of the representatives has shown some relevance in the variation, although in just half of the variants studied.

The opposite can be said, however, when we take into account Catalan nationalism, which for decades has divided individuals and parties in the debate on political sovereignty in Catalonia. In all of the cases analysed, nationalist politicians, but especially those who favour independence from Spain, create a style of speaking Spanish that contrasts qualitatively and quantitatively with the majority of nonnationalist politicians. In this style, the presence of numerous Catalan contact phenomena in speech stands out, such as loan words, syntactic calques, instances of code-switching and so on, but also the appropriation of certain phonetic variants.

However, what makes this specific case different from others in other political contexts (e.g. Krivoruchko 2008; Hall-Lew et al. 2010; Schrimpf 2013; Knoblock 2014; Podesva et al. 2015; Kirkham \& Moore 2016; Hall-Lew et al. 2017, among others) is that this process of appropriation gives rise to a preference for apparently opposite variants from a prescriptive angle. That is, in some cases, nationalist politicians are far ahead of the rest in the use of more vernacular forms, such as [1] or [t], while in others, it is the most prestigious variants in the pan-Hispanic context that are used the most (the case of [ð] both in inter-vowel contexts and in the final word position). This contrast is especially accentuated in the pronunciation of (d), since nationalist politicians lead in both vernacular -[t]- and standard -[ð]- uses, while, at the same time, they occupy the last positions in other more 'Castilian' variants, such as elisions and interdentalisations. However, this seeming contradiction is only illusory and shows how the same social meanings may be indexed by different linguistic variants, as long as they meet one condition: that, in all cases, they are the closest to the pronunciation of Catalan and, therefore, represent an authenticity and proximity to a (nationalist) ideal of Catalanhood. It should be stressed that, like other examples of agentivity studied in recent years - jocks and burnouts (Eckert 2008), Beijing yuppies and state managers (Zhang 2008), Scottish Labour and National Party MPs (Hall-Lew et al. 2017), and so on-nationalist and non-nationalist politicians are not born with these associated speech styles. Instead, they construct them in the course of social interactions within this particular political context. Therefore, we cannot exclude the possibility that these patterns of variation could differ in other scenarios.

In addition, the agentive nature of variation also serves to explain the speech of some individuals, whose patterns of variation depart from other politicians of the same 
group. In this sense, we have verified, for example, that the distancing of the most vernacular pronunciations on the part of the former nationalist leader Duran i Lleida runs parallel to his own distancing from the sovereignist theses defended by his former partisans. This fact could illustrate how a change in someone's identity (or interests) may result in a change in their linguistic practice (Drummond \& Schleef 2016:54). A similar, though to a large extent inverse case, is that of the Mayor of Barcelona, Ada Colau, whose middle-ground stance regarding independence is also reflected in her strategic use of the phonetic repertoire. And similar instances of symbolism and iconisation can be observed in the speech of the former leader of the Popular Party in Catalonia, Xavier Albiol, whose position is much closer to the indigenist pole of variation than other non-nationalist leaders, maybe in an attempt to find a place in a political scenario highly polarised by the prosovereignty debate.

All of the foregoing confirms the reality of the principle, well studied in variationist work on style in recent years, that the meanings of phonetic variables are largely underspecified, and gain more specific meanings in their contexts of use (Bucholtz \& Hall 2010; Eckert 2012, 2016; Drummond \& Schleef 2016). In this sense, the social meaning of $[\mathrm{t}]$ or $[1]$ cannot possibly be related specifically to any of these groups or identities. For some politicians, the use of these vernacular variants serves to construct a clearly pro-Sovereign discursive identity, while for others it is a means at the service of a difficult political equilibrium (Colau), or the way to find a place in a contentious political landscape (Albiol). Be that as it may, all of these senses appear connected to the same shared meaning: indexical values linked to authenticity and proximity to a sense of proper Catalanhood.

The panorama offered in these pages is bound to be limited. The study of how linguistic variation and identity condition each other cannot be limited to the analysis of a particular linguistic feature. And, although the results of various phonetic variables are presented in this article, this line of research on agentivity and indexicality should cover other phonetic phenomena, but also phenomena of a grammatical and lexical nature. This is a task, in any case, that I reserve for future research.

\section{NOTES}

* This study is part of the project 'Structural, social and idiolectal dimensions of linguistic change', funded by the Spanish Ministry of Economy and Competitiveness 
(Ref. FFI2017-86194-P) and the University Jaume I (Ref. UJI-B2017-01). I would like to thank Javier Lara and Brittani Cortés for their collaboration in the Sociolinguistic Lab of the University Jaume I, with several tasks related to the project. I also thank three anonymous reviewers as well as the editors for their insightful and constructive comments. Any remaining errors are my sole responsibility.

${ }^{1}$ The same happens with the spokesman of Esquerra Republicana de Catalunya in the Spanish Parliament, Gabriel Rufián, whose family background as immigrants probably implies a non-native command of Catalan.

${ }^{2}$ Only two of the sixteen politicians failed to complete their university studies (Albiol and Colau).

${ }^{3}$ Even though some of the Esquerra Republicana leaders reject the term Nationalist for themselves, I decided to group them with the rest of the nationalist forces, due to their common political cause over the history in defence of Catalanism interests, including the pro-independence movement. Moreover, in the Spanish — and Catalan - political imaginary, the characterisation of Esquerra Republicana as a Catalan nationalist party has been a constant since its creation in 1931.

${ }^{4}$ An exception to this norm is that of the ex-health minister, Dolors Montserrat, whose uses of this variant exceed by far (58\%) the indexes of the other variants, and are anomalous in the corpus.

\section{REFERENCES}

Alarcos, Emilio (1981). Fonología española. Madrid: Gredos.

Blas Arroyo, José Luis (2004). El español actual en las comunidades del ámbito lingüístico catalán. In Rafael Cano Aguilar (ed.), Historia de la Lengua Española, 1065-1086. Barcelona: Ariel.

- (2007). El contacto de lenguas como factor de retención en procesos de variación y cambio lingüístico: Datos sobre el español en una comunidad bilingüe peninsular. Spanish in Context 4(2):263-91.

(2011). Spanish in contact with Catalan. In Manuel Díaz-Campos (ed.), Handbook of Hispanic sociolinguistics, 374-94. Oxford: Blackwell. (2019). La sociolingüística del español en España. In Emilio Ridruejo Alonso (ed.), Manual de Lingüística Española, 582-613. Berlin: Mouton de Gruyter. 
Boersma, Paul, \& David Weenink (2006). Praat: Doing phonetics by computer. Online: http://www.fon.hum.uva.nl/praat/.

Bucholtz, Mary, \& Kira Hall (2010). Locating identity in language. In Carmen Llamas \& Dominic Watt (eds.), Language and identities, 18-28. Edinburgh: Edinburgh University Press.

Casanova, Julián (2007). República y Guerra Civil. Barcelona: Crítica/Marcial Pons.

Davidson, Justin (2015). Social dynamics of Catalan-Spanish contact in the evolution of Catalonian Spanish. Urbana-Champaign: University of Illinois, UrbanaChampaign dissertation.

Dowling, Andrew (2014). Accounting for the turn towards secession in Catalonia. International Journal of Iberian Studies 27(2):219-34.

Drummond, Rob, \& Erik Schleef (2016). Identity in variationist sociolinguistics. In Siân Preece (ed.), The Routledge handbook of language and identity, 50-65. London: Routledge.

Eckert, Penelope (2008). Variation and the indexical field. Journal of Sociolinguistics 12:453-76.

(2012). Three waves of variation study: The emergence of meaning in the study of sociolinguistic variation. Annual Review of Anthropology 41:87-100. (2016). Variation, meaning, and social change. In Nikolas Coupland (ed.), Sociolinguistics: Theoretical debates, 68-85. Cambridge: Cambridge University Press.

Estrada, Ana (2012). The loss of intervocalic and final /d/ in the Iberian Peninsula. Dialectologia, Special Issue III:7-22.

Fernández Planas, Ana María (2011). Así se habla: Nociones fundamentales de fonética general y española. Apuntes de catalán, gallego y euskara. Barcelona: Horsori.

García Moutón, Pilar, \& Isabel Molina (2015). La -/d/ en el Atlas Dialectal de Madrid: Un cambio en marcha. Lapurdu 19:277-90.

Giles, Howard; Nicholas Coupland; \& Justine Coupland (1991). Accommodation theory: Communication, context and consequence. In Howard Giles, Nicholas Coupland, \& Justine Coupland (eds.), Contexts of accommodation: Developments in applied sociolinguistics, 1-68. Cambridge: Cambridge University Press.

Hall-Lew, Lauren; Elizabeth Coppock; \& Rebecca Starr (2010). Indexing political persuasion: Variation in the Iraq vowels. American Speech 85(1):91-102. 
— Scottish members of the UK Parliament. Language Variation and Change 29:341-63.

Hawkey, James (2014). Meeting language-in-education policy aims: Catalonia in the twenty-first century. European Journal of Language Policy 6(1):5-21.

Hidalgo, Antonio, \& Mercedes Quilis (2012). La voz del lenguaje: Fonética y fonología del español. Valencia: Tirant Humanidades.

Hualde, José I. (2014). Los sonidos del español. Cambridge: Cambridge University Press.

Institut d'Estudis Catalans (2016). Gramàtica de la llengua catalana. Barcelona: Institut d'Estudis Catalans.

Jaffe, Alexandra (ed.) (2009). Stance: Sociolinguistic perspectives. New York: Oxford University Press.

Johnson, Daniel E. (2009). Getting off the GoldVarb standard: Introducing Rbrul for mixed-effects variable rule analysis. Language and Linguistics Compass 3(1):359-83.

Kiesling, Scott F. (2009). Style as stance: Stance as the explanation for patterns of sociolinguistic variation. In Alexandra Jaffe (ed.), Stance: Sociolinguistic perspectives, 171-94. Oxford: Oxford University Press.

Kirkham, Sam, \& Emma Moore (2016). Constructing social meaning in political discourse: Phonetic variation and verb processes in Ed Miliband's speeches. Language in Society 45(1):87-111.

Knoblock, Natalia (2014). Dialect as a marker of political orientation. Paper presented at 2014 LSA Annual Meeting. Minneapolis, Minnesota.

Krivoruchko, Julia G. (2008). Prepositional wars: When ideology defines preposition. In Dennis Kurzon \& Silvia Adler (eds.), Adpositions: Pragmatic, semantic and syntactic perspectives, 191-208. Amsterdam: John Benjamins.

Labov, William (1972). Sociolinguistic patterns. Philadelphia: University of Pennsylvania Press.

- (2001). Principles of linguistic change: Social factors. Oxford: Blackwell.

Lapesa, Rafael (1968). Historia de la lengua española. Madrid: Gredos.

Le Page, Robert, \& Katherin Tabouret-Keller (1985). Acts of identity. Cambridge: Cambridge University Press. 
Molina, Isabel (2016). Variación de la -/d/ final de palabra en Madrid: ¿Prestigio abierto o encubierto? Boletín de Filología 60(2):347-67.

Podesva, Robert J.; Jermay Reynolds; Patrick Callier; \& Jessica Baptiste (2015). Constraints on the social meaning of released /t/: A production and perception study of US politicians. Language Variation and Change 27:59-87.

Queen, Robin (2013). Gender, sex, sexuality, and sexual identities. In Jack Chambers \& Natalie Schilling (eds.), The handbook of language variation and change, 36886. Malden, MA: Wiley-Blackwell.

Samper, Jose Antonio (2011). Socio-phonological variation and change in Spain. In Manuel Díaz Campos (ed.), The handbook of Hispanic sociolinguistics, 98-120. Malden, MA: Wiley-Blackwell.

Schrimpf, Natalie (2013). Politics and dialect variation: A sociophonetic analysis of the Southern Vowel Shift in Middle TN. Online: http://www.linguisticsociety.org/files/3542-6849-1-SM.pdf.

Silverstein, Michael (2003). Indexical order and the dialectics of sociolinguistic life. Language and Communication 23(3-4):193-229.

Sinner, Carsten (2004). El castellano de Cataluña, Tübingen: Max Niemeyer.

Snell, Julia (2010). From sociolinguistic variation to socially strategic stylisation. Journal of Sociolinguistics 14(5):630-56.

Trudgill, Peter (1972). Sex, covert prestige and linguistic change in the urban British of Norwich. Language in Society 1:179-95.

Turell, María T. (1996). El contexto de la variación lingüística y su aplicación al estudio del morfema español -ADO. In Francisco Gutiérrez (ed.), El español, lengua internacional (1492-1992), 639-54. Murcia: Compobell.

Zhang, Qing (2008). Rhotacization and the 'Beijing smooth operator': The meaning of a sociolinguistic variable. Journal of Sociolinguistics 12:210-22.

\section{Address for correspondence:}

José Luis Blas-Arroyo

University Jaume I

Departamento de Filología y Culturas Europeas Av Sos Baynat S/N Castellon de la Plana 12071, Spain blas@fil.uji.es 
(Received 9 April 2019; revision received 10 January 2020; accepted 30 January 2020; final revision received 10 April 2020) 